\title{
Factors Influencing the Performance of Junior High School Students in Social Studies in the Bia East District of Ghana
}

\author{
Daniel Kwame Emilio \\ Social Sciences Department, Bia Lamplighter College of Education, Sefwi Debiso, Ghana
}

\begin{abstract}
The study therefore sought to identify the factors that influence the performance of students in Social Studies at Junior High Schools in the Bia East District of Ghana. Descriptive survey design was adopted for the study. A sample size of 310 pupils was used for the study through the stratified random sampling procedure. Data was collected using questionnaires and analysed using means and standard deviations. The study found that the school-related factors that influence academic performance of pupils include the classroom atmosphere, presence and adequacy of teaching and learning materials, supervision and monitoring and class size. Also, the study revealed that number of contact hours between teachers and students, teaching styles and methods, teachers' ability to complete syllabi and qualification of teachers are the teacher-related factors that influence academic performance of pupils. In addition, the study revealed that parental support in terms of provision of learning materials influence students' academic performance. Finally, the study found that students' attitude towards learning, their self-concept and motivation, punctuality and regular school attendance and their level of discipline influence their academic performance. It was recommended among other things that education policy makers ensure that there is effective supervision and monitoring in junior high schools.
\end{abstract}

Keywords: Academic Performance, Factors, Social Studies

This research is self-financed

DOI: $10.7176 / \mathrm{JEP} / 11-20-05$

Publication date:July $31^{\text {st }} 2020$

\section{Introduction}

In this era of globalization and technological revolution, education is considered as a first step for every human activity. Education is the most important social institution that influences and is influenced by other social institutions (Mpiani, 2012). It plays a vital role in the development of human capital and is linked with an individual's well-being and opportunities for better living (Battle \& Lewis, 2002). In this sense, Saxton (2000) argues that education ensures the acquisition of knowledge and skills that enable individuals to increase their productivity and improve their quality of life.

Due to the very importance of education, the quality of students' performance therefore remains at top priority for educators (Farooq, Chaudhry, Shafiq, \& Berhanu, 2011). In this regard, educators, researchers and other stakeholders of education have long been interested in discovering the factors that influence the academic performance of students. Adane (2013) has opined that academic achievement in school is the result of interplay of several factors.

The factors that influence the academic performance of students may be student related, parent or family related and school related (Crosnoe, Johnson \& Elder, 2004). These factors comprise the variables that can determine the academic performance of students. In terms of the school related factors, the variables can be related to the teachers, school atmosphere and physical facilities in the school. According to Adane (2013), several school environmental factors have generally been identified as influencing academic performance. These include availability of instructional materials, school location and quality of the physical facilities, class size and pupil-teacher ratios, teacher qualification and experience, and supervision. Anamuah-Mensah (2010), an educationist also attributed the phenomenon of poor performance of students to lack of effective supervision and monitoring at school, lack of motivation for teachers and inadequate number of qualified teachers to fill empty classrooms.

In terms of parent-related factors, Adane (2013) pointed out that academic performance of students can be influenced by a range of household factors such as socio-economic status (education, occupation and income), size of the household, type of discipline at home, family structure, and the level of parental involvement and interest in children's schooling. Thus, poverty, low level of parental education, parental and neighbourhood negative attitudes toward schooling in general significantly affect academic achievement negatively (Currie, 1995; Gregg \& Machin, 1999). The reverse is true. Children with high level of parental education have greater access to a wide variety of economic and social resources (family structure, home environment, parent-child interaction) that can be drawn upon to help their children succeed in school (Coleman, 2006).

Apart from the school and parental factors, factors related to the student's own characteristics can affect academic performance of students. Several students' characteristics have generally been identified as influences to their academic performance. These include time with books and homework, attendance in school, students' 
attitude towards schooling, students' self-concept and motivation, and the health and nutritional status of students (Adane, 2013).

According to Chowa, Masa, Ramos, and Ansong (2015), decades of research on the effects of student, family, and school characteristics on student academic achievement have attempted to understand the implications for school success globally. Globally, some studies have concluded that student characteristics such as gender, social background, and outlook play varying roles in the existence of achievement gaps and enrollment disparities (Filmer, 2005). Similarly, other studies have examined the role of family background characteristics, particularly economic status, on educational outcomes (Cockburn \& Dostie, 2007; Grimm, 2011). In closing the gap, schools try to resolve some of these issues that have led to the existence of the gaps.

In Africa, some studies have examined the effects of student traits and social background, such as academic self-efficacy and level of commitment to school, on academic achievement and identified an association between the variables (Christian \& Charles, 2013, Dramanu \& Balarabe, 2013, Etsey, 2005). For example, in Kenya, Lloyd, Mensch and Clark (2000) found that low performing schools were characterised by inadequate school facilities, lack of active participation of students in the teaching-learning process, and poor overall school atmosphere in terms of organisation, rules and student-to-student interaction. Thus, in different places in the world, the search for the factors has been intensive and has established that a combination of the factors relating to school, parents and students affect the academic performance of students (Crosnoe et al, 2004; Farooq et al, 2011).

In Ghana, government and other agencies responsible for education have consistently sought to identify the reasons behind the performance of students. All these are meant to help improve the academic performance of students. However, despite the increased investment and strides in several educational outcomes, quality of education and academic achievement have not improved (Akyeampong, 2009, Okyerefo et al., 2011, World Bank, 2010). Several authors and researchers have pointed to factors that may be school, parent or student related as responsible for the academic performance of students (Adane, 2013; Seddoh, 2013). Empirical studies therefore help identify the extent to which either of these factors influence academic performance of students. It is against this background that the current study seeks to investigate common factors that influence the academic performance of Senior High School students in St. Paul's Senior High School (SHS) in the Kwahu South District in Ghana.

Several variables or factors inside and outside the school environment affect students' quality of academic achievement (Farooq et al, 2011). Specifically, it has been identified that students perform better when there is more parental involvement (Goldring \& Shapira, 1996; Ho \& Willms, 1996), academic success is emphasized (Lytton \& Pyryt, 1998; Zigarelli, 1996), and the classroom climate is conducive to teaching and learning (Ma \& Klinger, 2000; Ma \& Willms, 1995). Again, school context factors such as class and school size are often considered in studies of factors influencing achievement.

Social Studies as a subject of study focuses on issues relating to personal character, private experiences and values (Dania, 2016). Dania indicated further that values are examined, appraised, interpreted to and altered to make it useful for individual in particular and the society at large. In Ghana, Social Studies education starts from elementary school through to the university. The goal of social studies is to foster affective concern amongst students (Dania, 2016). Therefore, Social studies assists individuals to demonstrate affection in practical ways.

In Ghana, academic achievement of students is thought of as very important. As such, several studies have been carried out to find out the factors responsible for the performance of students. For instance, Adane (2013) investigated factors that are responsible for the low academic achievement of pupils in Kemp Methodist Junior High School at Aburi in the Eastern region of Ghana and found school, teacher, student and home-related factors as responsible for the low academic performance of the students. By identifying these factors, recommendations were made to improve the situation. There have been reports that Social Studies education may be facing numerous challenges that affect the performance of students and the society as a whole (Bordoh, Eshun, Kofie, Bassaw, \& Kwarteng, 2015; Kankam, 2016; Yalley, 2017).

In the Bia East District, one of the nine Metropolitan, Municipal and District Assemblies (MMDAs) in the Western North Region, maximum attention has always been given to academic performance of students. In spite of this, there has not been any published empirical work on the academic performance of students at the Junior High School level. Regarding the performance of students in Social Studies, it has been realized that there have not been much attention paid to Social Studies compared to other subjects like Integrated Science and Mathematics (Yalley, 2017). The study therefore sought to identify the factors that influence the performance of students in Social Studies at Junior High Schools in the Bia East District of Ghana. Specifically, the study sought to answer the following questions:

1. What are the school-related factors that influence the performance of final year students in Social Studies at Junior High Schools in the Bia East District of Ghana?

2. What are the teacher-related factors that influence the performance of final year students in Social Studies at Junior High Schools in the Bia East District of Ghana? 
3. What are the parent-related factors that influence the performance of final year students in Social Studies at Junior High Schools in the Bia East District of Ghana?

4. What are the student-related factors that influence the performance of final year students in Social Studies at Junior High Schools in the Bia East District of Ghana?

\section{Literature Review}

\subsection{Theoretical Basis}

The study was founded on the Theory of Educational Productivity was used as the framework upon which the study was based. The theory was propounded by Walberg (1981). The Theory of Educational Productivity by Walberg (1981) determined three groups of nine factors based on affective, cognitive and behavioral skills for optimization of learning that affect the quality of academic performance. The factors are aptitude (ability, development and motivation); instruction (quantity and quality); and environment (home, classroom, peers and media) (Roberts, 2007). These nine factors which he termed to be productive factors were identified from syntheses of about 3000 individual studies of factors related to student learning (Fredrick \& Walberg, 1980; Walberg, 1984). Several studies have sought to establish the potency of the factors in determining learning and it has been found that no single factor is dominant in determining performance (Walberg, Fraser, \& Welch, 1986). In essence, all the nine factors work together to determine the academic performance of students.

The theory is relevant because the nine factors as depicted in the theory can all be related to the four main variables of the study. For instance, ability, development and motivation are connected to student-related factors in this study. Again, the quantity and quality of instruction is connected to the teacher-related factors in this study. Finally, the environmental factors of home, classroom, peers and media are connected to the factors of school and parent-related factors in this study.

\subsection{Empirical Review}

Farooq, Chaudhry, Shafiq, and Berhanub (2011) conducted a study to examine different factors influencing the academic performance of secondary school students in a metropolitan city of Pakistan. They found that socioeconomic status (SES) and parents' education have a significant effect on students' overall academic achievement as well as achievement in the subjects of Mathematics and English. The study of Farooq et al. (2011) focused on only the influence of parental factors on the education of their children. The current study however focused on other factors aside parental involvement. Regardless, the findings are of relevance in the current study.

Wilder (2014) synthesized the results of nine meta-analyses that examined the impact of parental involvement on the academic achievement of students. The results indicated that the relationship between parental involvement and academic achievement was positive. This finding was similar to that of Fuchs and Woessmann (2004) who revealed that parental education and occupation had more substantial effects on academic performance.

In terms of school factors, Fabunmi, Brai-Abu and Adeniji (2007) indicated that three class factors (class size, student classroom space and class utilization rate), when taken together, determined significantly students' academic performance in Oyo state, Nigeria. Similarly, Salfi and Saeed (2007) found a significant correlation between school size and students' achievement in Pakistan. They revealed that small schools performed better than medium and large schools. These findings confirmed the views of Adeyela (2000) that large class size is unconducive for serious academic work.

Kaimenyin (2013) explored the factors influencing academic performance of students in the Kenya Certificate of Secondary Education (KCSE) in Imenti North District and found that student's discipline was major determinant of academic performance. Availability of school resources was also found to significantly influence performance of students. Akessa and Dhufera (2015) conducted a study to examine different factors influencing the academic performance of students in higher institution case of Rift valley university Jimma campus Ethiopia. They found that teachers have a great role in fostering positive or negative attitude to achievements of students. There was also strong association between the academic performance (achievement) of students' GPA and fathers and mothers' education level. Similarly, there was a strong association between the academic achievement (GPA) of students' students and economic status of families.

In Ghana, some studies have been carried out concerning the factors that influence the academic performance of students. For instance, Adane (2013) sought to identify factors that are responsible for the low academic achievement of pupils in Kemp Methodist Junior High School at Aburi in the Eastern region of Ghana. Factors attributed to teachers, school environmental, parents and the pupils were primarily responsible for the low academic achievement of the pupils. The school factors identified included limited number of teachers with high academic qualification, inadequate teaching and learning materials, and misuse of contact hours with pupils. The teacher factors included lateness to school and absenteeism, inability to complete the syllabi and inadequate homework assigned to pupils. The pupil characteristics found significant were lateness to school and 
absenteeism, lack of assistance with studies at home and use of local language in the classroom. Home conditions or parental support variables causing pupils to perform poorly academically were their inability to provide textbooks and supplementary readers, low level of interaction with children's teachers, and low involvement in the Parent Teacher Association. The study of Adane (2013) was similar to the current study in the contexts of the specific objectives.

Seddoh (2013) was undertaken to investigate the factors affecting the academic performance of students of Dzolo Senior High School in the Volta Region of Ghana. Seddoh found that inadequate school infrastructure coupled with students' negative attitudes to learning added up to the leading causes of students' poor performance. Mpiani (2012) sought to obtain evidence of the factors that were responsible for the academic performance of pupils in the Asawasi Sub - Metro and found that persistent intrusion of the school premise by the public, ineffective use of teaching and learning materials (TLMs), and inadequate teaching and learning facilities disrupted teaching and learning and thus affected the academic performance of the pupils.

Etsey, Amedahe and Edjah (2004) in a study of 60 schools from peri-urban (29 schools) and rural (31 schools) areas in Ghana found that academic performance was better in private schools than public schools because of more effective supervision of work. Thus, they emphasised that effective supervision in schools is key to optimum academic performance. In a more expansive study, Etsey (2005) attributed the cause of poor academic performance in the Shama Sub-Metro of Shama Ahanta East Metropolitan Assembly (SAEMA) in Ghana to a combination of factors relating to the school environment, teachers, pupils and parents. Diaz (2003) also revealed that factors such as intellectual ability, poor study habit, achievement motivation, lack of vocational goals, low self-concept, low socioeconomic status of the family, poor family structure and anxiety as contributing to educational performance. In focusing only on parental or home factors, Ghanney (2007) examined the effects home environment has on the child's achievement in primary schools in Winneba Township and found that positive parental attitude towards education; great parental support and interest combine to enhance children's progress in education rather than the level of parent's educational attainment. Chowa, Masa, Ramos, and Ansong (2015) also examined student- and school-level predictors of academic achievement of Ghanaian junior high school students and revealed that age, gender, academic self-efficacy, and commitment to school were significantly associated with math and English scores. Class size and the presence of toilet facility were also significant predictors of English scores.

Generally, like most of the studies reviewed, the focus has been on all the factors that can influence students' academic performance, even though some of the studies were focused on single factors like parental factors. The review shows that there are several studies carried out in Ghana concerning the factors that influence academic performance of students. However, in the study area, St. Pauls SHS in the Kwahu South District, it appeared that no such study had been carried out. This created a gap to be bridged by the current study.

\section{Methodology}

The descriptive survey research design was adopted for the study. This design focuses on describing the relationships that exist, practices that prevail, beliefs and attitudes held, the processes that are going on and the effects or trends that are developing with regard to specific phenomenon (Best \& Khan, 2001). The design was deemed appropriate for the study because it helped in describing the views of pupils concerning the factors that influence their academic performance. The population for the study was made up of 1,613 pupils from 10 selected schools in the District. The population comprised 908 males and 705 females.

A sample size of 310 pupils was used for the study. The sample size was obtained using Krejcie and Morgan's (1970) sample size determination Table. Making reference from the Table, a sample of 310 is suitable for a population of 1,613. The sampling procedure that was used for this study was the stratified random sampling. The population was divided into relatively homogenous subsets called strata and then random samples are taken from each stratum. Specifically, the population was put into strata of schools. Thus, the number of pupils from each school was representative of the total population of the school. After the stratification, a simple random sampling was used to get the actual participants for the study.

Questionnaire was used in collecting the data for the study. The validity of the questionnaire was established experts in research and assessment at the University of Cape Coast. The reliability of the questionnaire was obtained by ascertaining the internal consistency using Cronbach Co-efficient Alpha. A reliability co-efficient alpha of 0.77 was obtained implying that the instrument was reliable for the study.

In collecting the data, the consent of the school authorities was obtained. After permission was obtained from the school authorities, days for the data collection were arranged and the questionnaires were administered to the respondents with the help of teachers in each school. These teachers were given some training on the ethical issues in research and the purpose of the study. After completion of the questionnaire, all the questionnaires were collected from the respondents as the respondents were not allowed to take questionnaires home. This helped ensure a $100 \%$ return rate of the questionnaires. The data collection was done within three working weeks. The data was analysed using means and standard deviations. 


\section{Results}

4.1 School-related Factors that Influence the Academic Performance of Students

The data were analysed using means and standard deviation. The results are presented in Table 1.

Table 1: School-Related Factors that Influence Academic Performance

\begin{tabular}{lcc}
\hline Statement & Mean & $\begin{array}{c}\text { Std. } \\
\text { Dev. }\end{array}$ \\
\hline The presence and state of school facilities affect academic performance of students & 4.11 & 0.69 \\
Supervision and monitoring of school work influence academic performance of students & 4.35 & 0.65 \\
Classroom atmosphere affect performance of students & 4.55 & 0.51 \\
Class size (number of students in class) affect academic performance of students & 4.19 & 0.68 \\
Presence and adequacy of teaching and learning materials affect academic performance of & 4.55 & 0.49 \\
students & &
\end{tabular}

Source: Field Survey

It can be seen from Table 1 that the statement 'Classroom atmosphere affect academic performance of students' recorded the highest mean of 4.55 and a standard deviation of 0.51 . This implies that most of the respondents agreed to this statement. The statement 'Presence and adequacy of teaching and learning materials affect academic performance of students' also recorded a mean of 4.55 and a standard deviation of 0.49 . The other significant statements were 'Supervision and monitoring of school work influence academic performance of students $(\mathrm{M}=4.35, \mathrm{SD}=0.65)$ ' and 'Class size (number of students in class) affect academic performance of students $(\mathrm{M}=4.19, \mathrm{SD}=0.69)$ '. Overall, it can be inferred that classroom atmosphere, presence and adequacy of teaching and learning materials, supervision and monitoring and class size influence academic performance.

\subsection{Teacher-related Factors That Influence the Academic Performance of Students}

The data were analysed using means and standard deviation. The results are presented in Table 2.

Table 2: Teacher-Related Factors that Influence Academic Performance

\begin{tabular}{lcc}
\hline Statement & Mean & $\begin{array}{l}\text { Std. } \\
\text { Dev. }\end{array}$ \\
\hline Qualification of teachers affect academic work of students & 3.80 & 0.68 \\
Number of teachers influence academic performance of students & 3.41 & 0.98 \\
Teaching styles and methods of teachers influence academic performance of students & 4.24 & 0.71 \\
Teachers' ability to complete syllabi influence students' academic performance & 4.07 & 0.63 \\
Number of contact hours between teachers and students influence students' academic & 4.22 & 0.63 \\
performance & & \\
\hline
\end{tabular}

Source: Field Survey

It can be seen from Table 2 that the statement 'teaching styles and methods of teachers influence academic performance of students $(\mathrm{M}=4.24, \mathrm{SD}=0.71)^{\prime}$ had the highest mean and thus is the most common factor. This was followed by 'number of contact hours between teachers and students influence students' academic performance $(\mathrm{M}=4.22, \mathrm{SD}=0.63)$ ' and 'teachers' ability to complete syllabi influence students' academic performance $(\mathrm{M}=4.07, \mathrm{SD}=0.63)$ '. It can therefore be inferred from the table, that the common teacher-related factors that influence academic performance are teaching styles and methods of teachers, number of contact hours between teachers and students and the ability of teachers to complete syllabi.

\subsection{Parent-related Factors that Influence the Academic Performance of Students}

The results of the analyses are presented in Table 3.

Table 3: Parent-Related Factors that Influence Academic Performance

\begin{tabular}{|c|c|c|}
\hline Statement & Mean & $\begin{array}{l}\text { Std. } \\
\text { Dev. }\end{array}$ \\
\hline Parents' educational level influence academic performance & 3.17 & 1.23 \\
\hline Parents' financial status influence academic performance & 4.15 & 0.66 \\
\hline $\begin{array}{l}\text { Parental support (provision of learning materials) for students influence academic } \\
\text { performance }\end{array}$ & 4.47 & 0.79 \\
\hline $\begin{array}{l}\text { Parents' interest in their children's academic work influence students' academic } \\
\text { performance }\end{array}$ & 4.29 & 0.46 \\
\hline Family structure (single-parent or intact family) influence students' academic performance & 3.51 & 1.08 \\
\hline
\end{tabular}


academic performance of students in St. Paul's SHS identified by the students.

4.4 Student-related Factors that Influence the Academic Performance of Students

The data was analysed using means and standard deviation. The results of the analyses are presented in Table 4.

Table 4: Student-Related Factors that Influence Academic Performance

\begin{tabular}{|c|c|c|}
\hline Statement & Mean & $\begin{array}{l}\text { Std. } \\
\text { Dev. }\end{array}$ \\
\hline Punctuality and regular school attendance influence the academic performance of students & 4.49 & 0.50 \\
\hline $\begin{array}{l}\text { Students' attitude towards teaching and learning influence the academic performance of } \\
\text { students }\end{array}$ & 4.48 & 0.50 \\
\hline Discipline among students influence the academic performance of students & 4.44 & 0.58 \\
\hline Students' self-concept and motivation influence their academic performance & 4.59 & 0.49 \\
\hline Students' health and nutritional status influence their academic performance & 3.93 & 0.98 \\
\hline
\end{tabular}

Source: Field Survey

From Table 4, it can be seen that the common student-related factors that influence student academic performance are students' self-concept and motivation $(\mathrm{M}=4.59, \mathrm{SD}=0.50)$, punctuality and regular school attendance $(\mathrm{M}=4.49, \mathrm{SD}=0.50)$ and students' attitude towards teaching and learning $(\mathrm{M}=4.48, \mathrm{SD}=0.50)$. Another significant factor identified is discipline among students $(M=4.44, S D=0.58)$. Thus, by implication, these are the common student-related factors that influence the academic performance of students as perceived by the students in the study.

\section{Discussion}

The study found that the school-related factors that influence academic performance of pupils include the classroom atmosphere, presence and adequacy of teaching and learning materials, supervision and monitoring and class size. These confirmed several other studies. For instance, Fabunmi, Brai-Abu and Adeniji (2007) found that three class factors (class size, student classroom space and class utilization rate), when taken together, determined significantly students' academic performance in Oyo state, Nigeria. In a similar vein, Salfi and Saeed (2007) found a significant correlation between school size and students' achievement in Pakistan. They revealed specifically that small schools performed better than medium and large schools. These findings also confirmed the views of Adeyela (2000) that large class size is unconducive for serious academic work.

Also, the study revealed that number of contact hours between teachers and students, teaching styles and methods, teachers' ability to complete syllabi and qualification of teachers are the teacher-related factors that influence academic performance of pupils. These findings are understandable since in the classroom, teaching styles and methods of teaching are important. The style and method of teaching can determine whether students understand what is being taught and ultimately influence the academic performance of students. The contact hours of teaching and learning is also connected to the ability of teachers to complete syllabi. These factors can determine how much benefits students gain from teaching and learning interactions. Again, the qualification of teachers can influence how effective teachers can be in their teaching. This will ultimately influence the academic performance of students. It is for this reason why the Ghana Education Service always seek to ensure that teachers who are entrusted with teaching of students are of the utmost quality and of high competence.

The findings of the current study support the findings of Adane (2013) that the teacher factors that were found to contribute to the low academic performance were incidences of lateness to school and absenteeism, inability to complete the syllabi, inadequate homework assigned to pupils and misuse of contact hours with pupils. In the same vein, Etsey (2005) attributed the cause of poor academic performance in the Shama SubMetro of Shama Ahanta East Metropolitan Assembly (SAEMA) in Ghana to a combination of factors relating to the school environment, teachers, pupils and parents.

In addition, the study revealed that parental support in terms of provision of learning materials influence students' academic performance. Again, parental interest in academic work as well as the financial status of parents can influence the academic performance of students. The findings are in agreement with the findings of Wilder (2014) that the relationship between parental involvement and academic achievement was positive. Adane (2013) also revealed that home conditions or parental support variables causing pupils to perform poorly academically were their inability to provide textbooks and supplementary readers, low level of interaction with children's teachers, and low involvement in the Parent Teacher Association. These have been given backing in the findings of the current study. Ghanney (2007) examined the effects home environment has on the child's achievement in primary schools in Winneba Township and found that positive parental attitude towards education, great parental support and interest combine to enhance children's progress in education rather than the level of parent's educational attainment.

Finally, the study found that students' attitude towards learning, their self-concept and motivation, punctuality and regular school attendance and their level of discipline influence their academic performance. In 
most situations, the attitude of students towards teaching can determine academic performance even when all the school, teacher and parental factors are in place. These findings give support to the findings of Diaz (2003) that factors such as intellectual ability, poor study habit, achievement motivation, lack of vocational goals and low self-concept contribute to the academic performance students. The study of Adane (2013) also showed that pupil characteristics that can influence academic performance included incidences of lateness to school and absenteeism. Lateness and absenteeism can make a student not get adequate contact hours with the teacher. As a result, the student is likely to have issues understanding some of the concepts taught by the teacher. In the long run, the academic performance of the student is likely to be affected. Again, the study of Kaimenyin (2013) in Imenti North District in Kenya found that student's discipline influences their academic performance. Seddoh (2013) argued therefore that, students' negative attitudes to learning added up to the leading causes of students' poor performance.

\section{Conclusions}

Based on the findings, I conclude that in support of several previous studies, the atmosphere and physical environment of a school are influential determinants of the academic performance of pupils in Social Studies in the Bia East District of Ghana. Aside the school-factors, issues of teaching methods and time spent in teaching are necessary in the academic performance of pupils. It has become evident that the importance of the right teaching methods and quality of teacher-student contact hours in academic performance of students cannot be undermined.

Further, parental support, interest in children's academic work and financial status need to be given serious consideration if the academic performance of pupils in the Bia East District is to be enhanced. Finally, it is concluded that student-related factors that revolved around attitude and motivation are important for optimum academic performance. Without the student-related factors, the other factors (school-related, teacher-related and parent-related) might not be able to bring about a change on their own.

\section{Recommendations}

Based on the findings and conclusions of the study, it is recommended that education policy makers ensure that there is effective supervision and monitoring in junior high schools. This can help improve the atmosphere in the school environment and also ensure that there is quality teacher-student contact time. It is also recommended that educational authorities ensure that there are enough classrooms so that there can be small class sizes thereby improving academic work of students.

Again, it is recommended that teachers put in efforts to ensure that syllabus are completed and students are encouraged to have more contact hours with teachers. It is also recommended that parents and teachers collaborate and consult in ensuring that students have the right attitude towards teaching and learning and are motivated enough to learn.

Since this study was focused on pupils, it is suggested that future research focus on teachers and parents to obtain their views on the factors that affect the performance of pupils. This can help obtain a balanced view and thus help make appropriate and specific recommendations for educational practice.

\section{References}

Adane, L. O. (2013). Factors affecting low academic achievement of pupils in Kemp Methodist Junior High School in Aburi, Eastern Region. Unpublished master's thesis, University of Ghana, Legon.

Adeyela, J. (2000). Problems of teaching science in large classes at the junior secondary school level: Implications for learning outcome. Unpublished master's thesis. University of Ibadan, Ibadan, Nigeria.

Anamuah-Mensah, J. (2010). Reaction to Daily Graphic Publication. Daily Graphic, Friday August $27,2010$.

Best, J. W., \& Khan, J. V. (2001). Research in education ( $7^{\text {th }}$ ed.). New Delhi, India: Prentice-Hall of India.

Bordoh, S., Eshun, I., Kofie, D., Bassaw, T. K., \& Kwarteng, P. (2015). Social studies teachers' content knowledge in senior high schools in the Sekondi-Takoradi Metropolis in the Western Region of Ghana. American Journal of Social Science Research, 1(3), 169-177.

Coleman, J. S. (2006). The adolescent society. Education Next, 6(1), 40-43.

Crosnoe, R., Johnson, K. M., \& Elder, H. G. (2004). School size and the interpersonal side of education: An examination of race/ethnicity and organizational context. Social Science Quarterly, 85(5), 1259-1274.

Currie, J. (1995). Welfare and the well-being of children: Fundamentals of Pure and Applied Economics No.59. Switzerland: Hardwood Academic Publishers.

Diaz, A. L. (2003). Personal, family, and academic factors affecting low achievement in secondary school. Electronic Journal of Research in Educational Psychology and Psychopedagogy, 1(1), 43-66.

Etsey, K. (2005). Causes of low academic performance of primary school pupils in the Shama Sub-Metro of Shama Ahanta East Metropolitan Assembly (SAEMA) in Ghana. Paper Presented at the Regional Conference on Education in West Africa, November 1-2, Dakar, Senegal, 2005. 
Etsey, Y. K. A., Amedahe, F. K., \& Edjah, K (2004). Do private primary schools perform better than public schools in Ghana? Unpublished Paper. Department of Educational Foundations, University of Cape Coast, Cape Coast.

Fabunmi, M., Brai-Abu, P., \& Adeniji, I. A. (2007). Class Factors as determinants of secondary school students' academic performance in Oyo State, Nigeria. Journal of Social Science, 14(3), 243-247.

Farooq, M. S., Chaudhry, A. H., Shafiq, M., \& Berhanu, G. (2011). Factors affecting students' quality of academic performance: A case of secondary school level. Journal of Quality and Technology Management, $7(2), 1-14$

Fredrick, W. C., \& Walberg, H. J. (1980). Instructional time. Evaluation in Education, 4, 117-118.

Fuchs, T., \& Woessmann, L. (2004). What accounts for international differences in student performance? A reexamination using PISA data. Munich: Labour Markets CESifo.

Ghanney, R. A. (2007). Effects of home environment on parental attitudes towards the educational attainment of primary school pupils in Winneba Township, Ghana. International Journal of Educational Research, 3(2), 259-266.

Gregg, P., \& Machin, S. (1999). Childhood disadvantage and success or failure in labour market. In D. Blanchflower, \& R. Freeman, (Eds.), Youth employment and joblessness in advanced countries. National Bureau of Economic Research, Cambridge.

Kankam, B. (2016). Social studies education in Ghana: A historical perspective (1940-Present). Proceedings of INCEDI 2016 Conference, 29th-31st August 2016, Accra, Ghana.

Lee, V. E., \& Zuze, T. L. (2011). School resources and academic performance in Sub-Saharan Africa. Comp. Educ. Rev., 55(3), 369-397.

Michaelowa, K., \& Wittmann, E. (2007). The cost, satisfaction, and achievement of primary education: Evidence from Francophone Sub-Saharan Africa. World Development, 29(10), 1699-1716.

Mpiani, G. O. (2012). Factors affecting academic performance of pupils in basic schools in Asawasi Sub-Metro in the Ashanti Region of Ghana. Unpublished dissertation, University of Cape Coast.

Osei-Mensah, F. (2012). Factors that influence the performance in general knowledge in art of senior high school students in Abura Asebu Kwamankese District in the Central Region. Unpublished master's thesis, Kwame Nkrumah University of Science and Technology (KNUST), Kumasi, Ghana.

Osuala, E. C. (2005). Research methodology. Enugu: New Generation Books.

Roberts, G. A. (2007). The effect of extracurricular activity participation in the relationship between parent involvement and academic performance in a sample of third grade children. Retrieved from https://www.lib.utexas.edu/etd/d/2007/robertsg11186/robertsg 11186.pdf

Salfi, N. A., \& Saeed, M. (2007). Relationship among school size, school culture and students' achievement at secondary level in Pakistan. International Journal of Educational Management, 21(7), 606-620.

Santibañez, L. (2006). Why we should care if teachers get A's: teacher test scores and student achievement in Mexico. Economics Education Review, 25(5), 510-520.

Seddoh, P. F. (2013). Factors affecting the academic performance of students of Dzolo Senior High School in the Volta Region of Ghana. Unpublished master's dissertation, University of Cape Coast, Cape Coast.

Stewart, E. B. (2007). School structural characteristics, student effort, peer associations, and parental involvement: The influence of school- and individual-level factors on academic achievement. Educ. Urban Soc., 40, 179-204.

Walberg, H. J. (1981). A psychological theory of educational productivity. In F. Farley, \& N. Gordon (Eds.), Psychology and education. Berkeley, CA: McCutchan.

Walberg, H. J. (1984). Improving the productivity of America's schools. Educational Leadership, 41, 19-30.

Walberg, H. J., Fraser, B. J., \& Welch, W. W. (1986). Test of a model of educational productivity among senior high school students. The Journal of Educational Research, 79(3), 133-139.

Wilder, S. (2014). Effects of parental involvement on academic achievement: A meta-synthesis. Educational Review, 66(3), 377-397.

Yalley, C. E. (2017). Renaissance of social studies instruction in the senior high schools in Ghana: Technological perspective. Journal of Education and Practice, 8(13), 101-107.

Zuze, T. L. (2010). Human resource inputs and educational outcomes in Botswana's schools: Evidence from SACMEQ and TIMMS Stellenbosch Economic Working Papers 16/10. Department of Economics, Stellenbosch University, Stellenbosch, South Africa. 